\title{
Quito Municipal Schools-Cohort Study: Self-Perception of Body Image and Factors Related with It
}

\author{
Natalia Romero-Sandoval1,2,6, Oscar Flores ${ }^{3,6}$, Carmen Egas,,6, Gabriela Villamar ${ }^{4,6}$, \\ Zuleica Larrea,6, Manuel Cruz ${ }^{4,6}$, Laura Icaza, ${ }^{1,6}$, Miguel Martín ${ }^{5,6}$ \\ ${ }^{1}$ Universidad Internacional del Ecuador, Facultad de Ciencias Médicas, de la Salud y la Vida, Escuela de \\ Medicina, Quito, Ecuador \\ ${ }^{2}$ Postgrado de Medicina Familiar y Comunitaria, Área de la Salud, Universidad Nacional de Loja, Loja, Ecuador \\ ${ }^{3}$ Unidad Metropolitana de Salud Centro, Municipio del Distrito Metropolitano de Quito, Quito, Ecuador \\ ${ }^{4}$ Postgrado de Medicina Familiar y Comunitaria, Facultad de Ciencias Médicas, Universidad Central del Ecuador, \\ Quito, Ecuador \\ ${ }^{5}$ Unidad de Bioestadística, Facultad de Medicina, Universidad Autónoma de Barcelona, Barcelona, España \\ ${ }^{6}$ Grups de Recerca d'Amèrica i Àfrica Llatines-GRAAL, Barcelona, España \\ Email: nromero@internacional.edu.ec
}

Received 28 May 2014; revised 28 June 2014; accepted 28 July 2014

Copyright (C) 2014 by authors and Scientific Research Publishing Inc.

This work is licensed under the Creative Commons Attribution International License (CC BY).

http://creativecommons.org/licenses/by/4.0/

c) (i) Open Access

\section{Abstract}

Self-perception of body image is one factor to be considered when planning and performing preventive initiatives and interventions in childhood and adolescence. The aim of this study was to analyse self-perception of body image in relation to body-mass index, physical inactivity, not eating breakfast, dieting, smoking and alcohol consumption or toxic habits. Materials and Methods: using data from the "Quito municipal schools" cohort study 6964 students aged from 9 to 17 years were described using a multivariate log linear model of the multidimensional table generated by the variables. A logistic regression model was then fitted to assess associations via OR. Results: 8.2\% perceived themselves as overweight. Of those subjects overweight according to their BMI, $\mathbf{2 1 . 8 \%}$ perceived themselves as such, while among those not overweight according to BMI, $96.8 \%$ considered themselves as slim or of normal weight. Among students who were dieting, 15.1\% perceived themselves as overweight. Among those pupils who perceived themselves has having excess weight, the most common reasons for dieting were: lose weight $(56.8 \%)$, be healthier $(22.6 \%)$, and maintain current weight (8.4\%). Self-perception of excess weight interacts with excess weight ( $\left(\mathrm{R}_{\text {adjusted }} 8.42 ; \mathrm{CI}_{95 \%} 6.92\right.$ - 10.25), no breakfast (OR ${ }_{\text {adjusted }} 2.83$; $\mathrm{CI}_{95 \%} 2.13$ - 3.77), diet $\left(O R_{\text {adjusted }} 2.38 ; \mathrm{CI}_{95 \%} 1.95-2.89\right)$, and with all the variables except toxic habits $\left(0 R_{\text {adjusted }} 1.01\right.$; $\mathrm{CI}_{95 \%} 0.78$ a 1.29). Conclusion: Interventions to prevent obesity in childhood and adolescence ought to take account of specific determinants within the personal, behavioural and socio-envi- 
ronmental factors, such as the promotion of a positive body image.

Keywords

Body Image, Self-Perception, Overweight and Obesity, School Children, Ecuador

\section{Introduction}

Several systematic reviews have highlighted the serious problem of overweight and obesity in children and young people, based on prevalence estimates, which for most countries lie between $20 \%$ and $30 \%$ [1]. In Latin America, the prevalence of overweight or obesity estimated for the population aged 0 to 19 years is between $20 \%$ and 25\%; roughly speaking, this translates into several tens of millions of affected children and adolescents [2]. The conclusion, repeatedly reached, is that preventive measures are necessary. Preventive measures for overweight in childhood and adolescence are issues that directly involve health authorities, those responsible for the health and education of children and adolescents, caregivers of primary care, and parents, not to mention the children themselves [3].

As with any chronic health problem it is very difficult to take preventive measures without knowing how it is perceived by those most affected, in this case children and adolescents. The study entitled "Quito municipal schools cohort study: Baseline results" investigating 6964 pupils between their sixth and tenth year of basic education during the 2010-2011 academic year, reported that $18.7 \%\left(\mathrm{CI}_{95 \%} 17.8\right.$ - 19.6) were overweight, and 7.9\% ( $\mathrm{CI}_{95 \%} 7.6$ - 8.2) were obese (excess weight: 26.6\%) (Natalia Romero-Sandoval et al., 2012) [4].

In study mentioned above, self-perception of body image was reported at baseline, by 6545 pupils (93.9\%) of whom $7.5 \%$ considered themselves overweight and $0.7 \%$ obese (excess weight: $8.2 \%)$; $5.4 \%\left(\mathrm{CI}_{95 \%} 4.87\right.$ - 5.94) reported not breakfasting every day, with differences between the sexes: $6.8 \%\left(\mathrm{CI}_{95 \%} 6.0-7.6\right)$ in girls, $3.7 \%$ ( $\left.\mathrm{CI}_{95 \%} 3.1-4.4\right)$ in boys, and $91.9 \%$ of pupils were sedentary or did only light physical activity.

Body image is a multidimensional construct, which broadly describes one's internal, subjective, representation of body size, outline and shape and the feelings, which accompany its characteristics, and those of its different parts [5]. Conception of body image is not only a product of internal perception but is, like so many other concepts, also influenced by context, and it is precisely in this aspect where social influence has the strongest impact [6].

In the context of the "Quito Municipal schools cohort study" we proposed to analyse self-perception of body image in relation to body mass index, as well as other factors such as sedentarism, not breakfasting, dieting, smoking and alcohol consumption, in order to try to understand better the behaviour of intervening factors regarding the prevalence found for self-perception of excess weight.

\section{Method}

\subsection{Population}

The present study includes 6964 pupils aged 9 to 17 years, participants of the so-called "Quito municipal schools" cohort study. The study is being conducted in 21 schools of the Quito Metropolitan District. All students matriculated in these schools participate in the study. The Quito research team developed a self-administered questionnaire. Compliance with ethical considerations and criteria of inclusion and exclusion have been explained elsewhere [4].

\subsection{Variables}

The anthropometric variable was the presence of excess weight (WEx-overweight or obesity) defined through the WHO classification of Body Mass Index for the population aged 5 to 19 years [7]. Dieting (Di), breakfasting (B) [8] and smoking and/or drinking (Th-toxic habits) [9] were conceptualised as dichotomic variables (yes/no). Not engaging in physical activity (Se) was dichotomised as sedentary/not sedentary based on the INTA questionnaire cutoff point [10]. The study objective variable was self-perception of body image (Au) which was 
measured using a visual scale of nine silhouette images. The same ones for both males and females, which provide a subjective estimate of weight (self-perception of body image) distributed over a continuous range covering from a very slim silhouette $($ score $=1)$ to a very fat one (score $=9$ ), with a score of 5 corresponding to a normal-weight silhouette [11]-[13]. The pupil had to choose the image which best represented their own silhouette. This scale was presented on a full page placed at the end of the questionnaire, which was self-administered. Responses were subsequently recoded into two categories: excess weight (images corresponding to overweight and obese), and not excess weight (images corresponding to thin and normal). Reasons why pupils were dieting were recorded for descriptive purposes. The other variables examined were: sex (G), and age Group (A) in two categories, 9 to 12 years and 13 to 17 years.

\section{Statistical Analysis}

The multivariate descriptive analysis of this study, using log linear models, aimed to simplify reality while maintaining its verisimilitude, determining which associations in the multidimensional table were significant. Binary interactions were selected by the forward method. Of all the models fitted, the most parsimonious was chosen (lowest number of parameters; i.e. highest number of degrees of freedom). Of models fitted with similar levels of parsimony we chose those that were easiest to interpret. Comparison between observed and expected frequencies was analysed using Likelihood Ratios (LR) and their significance assessed with a $p$-value greater than or equal to 0.05

On the basis of this result the associations between variables, derived from the model, are reported giving both crude and adjusted OR, 95\% confidence intervals and prevalence rates (PR). Analyses were conducted using the package SPSS v.21.

\section{Results}

Of the total of 6964 pupils, 3708 (53.3\%) were girls; 3567 (51.2\%) were aged between 9 and 12 years, and 1853 (26.6\%) scored for excess weight; 372/6939 (5.4\%) reported not breakfasting, and 1219/6695 (18.2\%) reported they were not following any type of diet. Of the 6450 pupils who answered the questions about smoking and/or alcohol consumption, 3521 (54.6\%) were classified as having toxic habits, 2884/4982 (57.9\%) did not engage in any physical activity, and 536 pupils of the 6545 (8.2\%) who answered the question on self-perception of body image self-perceived themselves as having excess weight.

Among those whose BMI classified them as having excess weight, 382/1749 (21.8\%) self-perceived themselves as such, and among those not classified as having excess weight $4642 / 4796$ (96.8\%) considered themselves to be normal or thin.

Finally, the reasons for dieting as reported by the pupils were: to be healthier $42.4 \%$, to lose weight $31.2 \%$, to maintain their weight $13.1 \%$, and due to illness 5.4\%. Among pupils dieting 155 (15.1\%) self-perceived themselves with excess weight, and 870 (84.9\%) dieted but did not perceive themselves as having excess weight.

Among those pupils who perceived themselves has having excess weight, the most common reasons for dieting were: lose weight 88/155 (56.8\%), be healthier 35 (22.6\%), and maintain current weight 13 (8.4\%). Among those who perceived themselves as normal, the reasons for dieting were: be healthier 368 (42.3\%), lose weight 270/870 (31.0\%) and maintain current weight 120 (13.8\%).

A log-linear analysis of the eight-dimensional table resulted in the model presented below, Equation (1).

$$
\begin{aligned}
\ln f_{i j k l m n o}= & C t e+A u+W E x+D i+A+G+B+S e+T h+A u * W E x+A u * D i \\
& +A u * A+A u * G+A u * B+A u * S e+A u * T h+D i * W E x+D i * T h
\end{aligned}
$$

The LR of this model was 257.76, with 225 degrees of freedom and p value 0.066 .

As may be appreciated, two binary interaction terms in the model are not associated with self-perception, but necessary in order to fit the model: dieting with excess weight $\left(D i^{*} W E x\right)$, and dieting with toxic habits ( $\left.D i^{*} T h\right)$. The association between dieting and excess weight showed that among those following a diet (1519; 18.21\%), $41.92 \%$ had excess weight, whereas among the 5476 (81.79\%) not dieting $23.32 \%$ had excess weight $\left(\mathrm{OR}_{\text {crude }} 2.37\right.$ $\mathrm{CI}_{95 \%} 2.08$ - 2.70; $\mathrm{PR} 1.80 \mathrm{CI}_{95 \%} 1.24$ - 1.95). the association between dieting and toxic habits showed that among those following a diet (1519; 18.21\%), 41.92\% had excess weight, whereas among the 5476 (81.79\%) not dieting 23.32\% had excess weight $\left(\mathrm{OR}_{\text {crude }} 2.37 \mathrm{CI}_{95 \%} 2.08\right.$ - 2.70; PR $1.80 \mathrm{CI}_{95 \%} 1.24$ - 1.95). These latter two interac- 
tions do not have any additional effect on the relationships between self-perception and the remaining variables since the terms $A u^{*} D i^{*} W E x$ and $A u^{*} B^{*} W E x$ were not significant.

Table 1 describes the binary associations between self-perception of body image and the rest of variables, providing crude OR with its $\mathrm{CI}_{95 \%}$, and the ratios of proportions. All variables are associated with self-perception of excess weight; for example the probability of self-perception of excess weight is $68 \%$ more in women than in men.

Table 2 presents adjusted OR for the associations between self-perception of body image and the other variables in the model. Self-perception of excess weight interacts with excess weight ( $\mathrm{OR}_{\text {adjusted }}$ 8.42; $\mathrm{CI}_{95 \%} 6.92$ 10.25), no breakfast ( $\mathrm{OR}_{\text {adjusted }} 2.83$; $\mathrm{CI}_{95 \%} 2.13$ - 3.77), diet $\left(\mathrm{OR}_{\text {adjusted }} 2.38 ; \mathrm{CI}_{95 \%} 1.95\right.$ - 2.89), and with all the variables. In the case of students who had toxic habits, the association with self-perception of excess weight had a non-significant adjusted OR of $1.01\left(\mathrm{CI}_{95 \%} 0.78\right.$ - 1.29).

\begin{tabular}{|c|c|c|c|c|c|c|c|}
\hline Variable & & $\begin{array}{c}\mathrm{n} \\
(\%)\end{array}$ & $\begin{array}{c}\text { Self-perception } \\
\text { of excess weight (\%) }\end{array}$ & $\mathrm{OR}_{\text {crude }}$ & $\mathrm{CI}_{95 \%}$ & $\mathrm{PR}^{\mathrm{a}}$ & $\mathrm{CI}_{95 \%}$ \\
\hline \multirow[t]{2}{*}{ Gender (G) } & Male & $3042(46.48)$ & 5.98 & 1.77 & $1.47-2.13$ & 1.68 & $1.43-2.01$ \\
\hline & Female & 3503 (53.52) & 10.11 & & & & \\
\hline \multirow[t]{2}{*}{ Age group (A) (years) } & 9 to 12 & 3350 (51.18) & 6.00 & 1.83 & $1.53-2.20$ & 1.75 & $1.48-2.07$ \\
\hline & 13 to 17 & 3195 (48.82) & 10.49 & & & & \\
\hline \multirow[t]{2}{*}{ Weight excess (WEx) } & Yes & 1749 (26.72) & 21.84 & 8.42 & $6.92-10.25$ & 6.80 & $5.68-8.13$ \\
\hline & No & 4796 (73.28) & 3.21 & & & & \\
\hline \multirow[t]{2}{*}{ Breakfast (B) } & Yes & $6181(94.71)$ & 7.57 & 2.83 & $2.13-3.77$ & 2.49 & $1.97-3.15$ \\
\hline & No & 345 (5.29) & 18.84 & & & & \\
\hline \multirow[t]{2}{*}{ Diet (Di) } & Yes & 1150 (18.22) & 14.70 & 2.38 & $1.95-2.89$ & 2.16 & $1.83-2.58$ \\
\hline & No & $5162(81.78)$ & 6.80 & & & & \\
\hline \multirow[t]{2}{*}{ Toxic habits (Th) } & Yes & 3431 (54.62) & 9.09 & 1.28 & $1.06-1.53$ & 1.25 & $1.06-1.48$ \\
\hline & No & $2851(45.38)$ & 7.26 & & & & \\
\hline \multirow[t]{2}{*}{ Sedentarism (Se) } & Yes & 2717 (57.83) & 9.16 & 1.54 & $1.23-1.92$ & 1.49 & $1.21-1.83$ \\
\hline & No & 1981 (42.17) & 6.16 & & & & \\
\hline
\end{tabular}

${ }^{\mathrm{a}} \mathrm{PR}=$ Prevalence Rate.

Table 2. Adjusted associations between self-perception of body image and study variables.

\begin{tabular}{cccc}
\hline & OR $_{\text {adjusted }}{ }^{\mathrm{a}}$ & $\mathrm{CI}_{95 \%}$ & $p$ value \\
\hline Gender (G) & 1.70 & $1.32-2.18$ & $<0.001$ \\
Age group (A) & 2.84 & $2.19-3.70$ & $<0.001$ \\
Excess weight (WEx) & 10.76 & $8.30-13.95$ & $<0.001$ \\
Breakfast (B) & 1.55 & $1.01-2.38$ & 0.044 \\
Diet (Di) & 1.49 & $1.14-1.96$ & 0.004 \\
Toxic habits (Th) & 1.01 & $0.78-1.29$ & 0.96 \\
Sedentarism (Se) & 1.60 & $1.24-2.06$ & $<0.001$ \\
\hline
\end{tabular}

${ }^{\mathrm{a}}$ Reference categories: male, 9 to 12 years, no excess weight, yes breakfast, no diet, no toxic habits, no sedentarism. 


\section{Discussion}

The perception of one's body image constitutes a representation defined based on life history and the affectivesocial-historic context of the moment, and therefore it refers to a set of representations, perceptions, feelings and attitudes which the individual has elaborated with respect to their body during its existence, through a variety of habits and external influences [14]. In this study we proposed to analyse the interactions of a series of habits which should differentiate the perception of body image in overweight or obese children and adolescents. The use of the log-linear model allowed us to obtain information about binary interactions, which would have gone unnoticed if tackled using logistic regression modelling.

Two associations, while not related with the body image self-perception variable, contribute when fitting the model by providing interesting information about the behaviour of these pupils. These two associations (of dieting with excess weight, of dieting with toxic habits) indicate a true higher presence of excess weight among the pupils who declared dieting. This statistical association, while it may not be causal, leads one to ask whether they dieted because of excess weight, or whether the diet itself caused a weight gain. Similarly, the association between toxic habits and dieting could be interpreted as an increase in toxic habits among school children who report dieting. In 2012 we published, for this group of pupils, the association between excess weight and not breakfasting, as it was found that the crude OR for weight excess and not breakfasting of 1.44 (CI 95\% 1.16 1.80) was strengthened after adjustment by age, sex, family type, family stage, sedentarism and health zone: OR 1.54 (CI 95\% 1.16 - 2.05) [15].

The present analysis of self-perception of body image revealed a high percentage of pupils who perceive themselves erroneously (21.8\% among those with excess weight), results similar to those found in other Latin American reports [16] [17]. Self-perceiving body image as overweight or obese was in all cases more common among the pupils who were any of: female, aged over 12 years (i.e. 13 to 17 years), did not breakfast, dieted, or sedentary. The fact of having toxic habits loses significance after adjustment for all the other variables.

Of all the variables analysed, the situation which presented the strongest association with self-perception of weight was the excess of measured weight, this tendency persisting when comparing the crude OR (8.42) with the adjusted OR in the model (10.76). These findings are of concern, above all if we consider that the majority of pupils with excess weight (overweight and obese) do not perceive themselves as such, making it more difficult to understand the guidance measures and the effect of counseling.

On the other hand it is noteworthy that a considerable percentage of pupils who perceive themselves as having excess weight follow a diet to reduce weight, do not breakfast, and are sedentary. Despite not perceiving themselves as having excess weight, some pupils still diet; moreover it is also serious that in more than half, the reason given for dieting was to live a healthier life.

Those adolescent females who do not breakfast, tend to eat more, eat fast and do no exercise, are the ones most likely to over-estimate their body image [18]. Not eating breakfast has been associated with dissatisfaction with body image and with ignorance about what is meant by healthy eating [19]. Differences in the prevalence of overweight/obesity with the perception of body image can be explained by differences in age, diet, habits dietetics and life and socio-economic level [20]. Differences in the prevalence of excess weight recorded by measuring BMI and perceived body image have clinical implications, including eating disorders. This aspect should be considered in efforts to advance guidance to adolescents and their families [21].

Interventions to prevent childhood and adolescent obesity should tackle specific determinants, within the set of personal, behavioural and socio-environmental factors, such as promotion of a positive image of the body, and reduction of unhealthy weight controlling behaviours [22].

\section{Limitations}

We recognise that in this study the measurement of perception of body image, which may depend on the scale used, could introduce a variety of restrictions on the associations reported.

\section{Acknowledgements}

MM was financed by the Prometeo Program, SENESCYT-Universidad Yachay-Universidad Central del Ecuador during September-December 2013. CE, GV, ZL and MC had grants from the Ministry of Health of Ecuador for the residency program of Family and Community Medicine, 2010-2013 period. 


\section{References}

[1] Bibiloni, M.D.M., Pons, A. and Tur, J.A. (2013). Prevalence of Overweight and Obesity in Adolescents: A Systematic Review. ISRN Obesity, 2013, ArticleID: 392747. http://dx.doi.org/10.1155/2013/392747

[2] Rivera, J.Á., de Cossío, T.G., Pedraza, L.S., Aburto, T.C., Sánchez, T.G. and Martorell, R. (2014). Childhood and Adolescent Overweight and Obesity in Latin America: A Systematic Review. The Lancet. Diabetes \& Endocrinology, 2, 321-332. http://dx.doi.org/10.1016/S2213-8587(13)70173-6

[3] Cowgill, B.O., Chung, P.J., Thompson, L.R., Elijah, J., Lamb, S., Garcia, V.P. and Bastani, R. (2014). Parents’ Views on Engaging Families of Middle School Students in Obesity Prevention and Control in a Multiethnic Population. Preventing Chronic Disease, 11, e54. http://dx.doi.org/10.5888/pcd11.130138

[4] Romero-Sandoval, N., Ruiz, V., Quizanga, J., Recalde, R., Anchali, E., Falconí, J., ... Martín, M. (2012). “Quito Municipal Schools” Cohort Study: Baseline Results. Open Journal of Epidemiology, 2, 70-74. http://dx.doi.org/10.4236/ojepi.2012.23011

[5] Casini, V., Augspach, L. and Guerra, L. (2008). Asociación entre la autopercepción de la imagen corporal y el estado nutricional en escolares de 6 a 14 años. Revista Electrónica de Ciencias Aplicadas Al Deporte, 1.

http://romerobrest.edu.ar/ojs/index.php/ReCAD/article/view/68

[6] Amaya-Hernández, A., Alvarez-Rayón, G.L. and Mancilla-Díaz, J.M. (2010). Insatisfacción corporal en interacción con autoestima, influencia de pares y dieta restrictiva: Una revisión/Body dissatisfaction in interaction with self-esteem, peer influence and dietary restraint: A systematic review. Revista Mexicana de Trastornos Alimentarios/Mexican Journal of Eating Disorders, 1, 76-89.

[7] Onis, M. de, Onyango, A.W., Borghi, E., Siyam, A., Nishida, C. and Siekmann, J. (2007). Development of a WHO Growth Reference for School-Aged Children and Adolescents. Bulletin of the World Health Organization, 85, 660-667. http://dx.doi.org/10.2471/BLT.07.043497

[8] Instituto Nacional de Estadística. Ministerio de Sanidad y Consumo. España. (2006). Encuesta Nacional de Salud. Cuestionario de Menores. (Personas de 0 a 15 años).

http://www.msssi.gob.es/estadEstudios/estadisticas/encuestaNacional/encuestaNac2006/ENS 06 Menores definitivo. pdf

[9] Warren, C.W., Riley, L., Asma, S., Eriksen, M. P., Green, L., Blanton, C., ... Yach, D. (2000). Tobacco Use by Youth: a Surveillance Report from the Global Youth Tobacco Survey Project. Bulletin of the World Health Organization, 78, 868-876.

[10] Godard, C., Rodríguez, M. del P., Díaz, N., Lera, L., Salazar, G. and Burrows, R. (2008). Valor de un test clínico para evaluar actividad física en niños. Revista Médica de Chile, 136, 1155-1162. http://dx.doi.org/10.4067/S0034-98872008000900010

[11] Stunkard, A.J., Sørensen, T.I.A., Hanis, C., Teasdale, T.W., Chakraborty, R., Schull, W.J. and Schulsinger, F. (1986). An Adoption Study of Human Obesity. New England Journal of Medicine, 314, 193-198. http://dx.doi.org/10.1056/NEJM198601233140401

[12] Gómez-Peresmitré, G., Saucedo-Molina, T. and Unikel, C. (2001). Imagen corporal en los trastornos de la alimentación: La Psicología Social en el campo de la salud. In Psicología social; Investigación y aplicaciones en México. México: México: Fondo de Cultura Económica.

[13] Côrtes, M.G., Meireles, A.L., Friche, A.A. de L., Caiaffa, W.T. and Xavier, C.C. (2013). [Silhouette Scales and Body Satisfaction in Adolescents: A Systematic Literature Review]. Cadernos de Saúde Pública, 29, 427-444. http://dx.doi.org/10.1590/S0102-311X2013000300003

[14] Rodríguez-Rodríguez, E., Aparicio, A., López-Sobaler, A.M. and Ortega, R.M. (2009). Percepción del peso corporal y medidas adoptadas para su control en población española. Nutrición Hospitalaria, 24, 580-587.

[15] Romero-Sandoval, N., Guanopatin, A., Gallegos, G., Collaguazo, A., Sáenz, P., Latorre, V., ... Martín, M. (2013). Breakfast Habits and Family Structure Associated with Overweight and Obesity in General Basic Students, Ecuador. British Journal of Medicine and Medical Research, 3, 128-139. http://www.sciencedomain.org/abstract.php?iid=163\&id=12\&aid=761\#.U11X8VfeTCs http://dx.doi.org/10.9734/BJMMR/2013/2144

[16] Madrigal-Fritsch, H., Irala-Estévez, J. de, Martínez-González, M.A., Kearney, J., Gibney, M. and Martínez-Hernández, J.A. (1999). Percepción de la imagen corporal como aproximación cualitativa al estado de nutrición. Salud Pública de México, 41, 479-486. http://dx.doi.org/10.1590/S0036-36341999000600008

[17] Pérez Rodríguez, U. (2013). La percepción e insatisfacción corporal en el alumnado de Educación Secundaria de la ciudad de Jaén. Revista de Investigación en Educación, 11. http://webs.uvigo.es/reined/ojs/index.php/reined/article/view/695/277

[18] Mori, K., Sekine, M., Yamagami, T. and Kagamimori, S. (2009). Relationship between Body Image and Lifestyle 
Factors in Japanese Adolescent Girls. Pediatrics International, 51, 507-513. http://dx.doi.org/10.1111/j.1442-200X.2008.02771.X

[19] Arora, M., Nazar, G.P., Gupta, V.K., Perry, C.L., Reddy, K.S. and Stigler, M.H. (2012). Association of Breakfast Intake with Obesity, Dietary and Physical Activity Behavior among Urban School-Aged Adolescents in Delhi, India: Results of a Cross-Sectional Study. BMC Public Health, 12, 881. http://dx.doi.org/10.1186/1471-2458-12-881

[20] Legleye, S., Beck, F., Spilka, S., Chau, N. (2014) Correction of Body-Mass Index Using Body-Shape Perception and Socioeconomic Status in Adolescent Self-Report Surveys. PLoS ONE, 9, Article ID: e96768.

[21] Curtin, C., Pagoto, S. and Mick, E. (2013) The Association between ADHD and Eating Disorders/Pathology in Adolescents: A Systematic Review. Open Journal of Epidemiology, 3, 193-202. http://dx.doi.org/10.4236/ojepi.2013.34028

[22] Wall, M., Larson, N., Haines, J. and Neumark-Sztainer, D. (2013) Personal, Behavioral and Socio-Environmental Predictors of Overweight Incidence in Young Adults: 10-yr Longitudinal Findings. The International Journal of Behavioral Nutrition and Physical Activity, 10, 37. http://dx.doi.org/10.4236/ojepi.2013.34028 
Scientific Research Publishing (SCIRP) is one of the largest Open Access journal publishers. It is currently publishing more than 200 open access, online, peer-reviewed journals covering a wide range of academic disciplines. SCIRP serves the worldwide academic communities and contributes to the progress and application of science with its publication.

Other selected journals from SCIRP are listed as below. Submit your manuscript to us via either submit@scirp.org or Online Submission Portal.
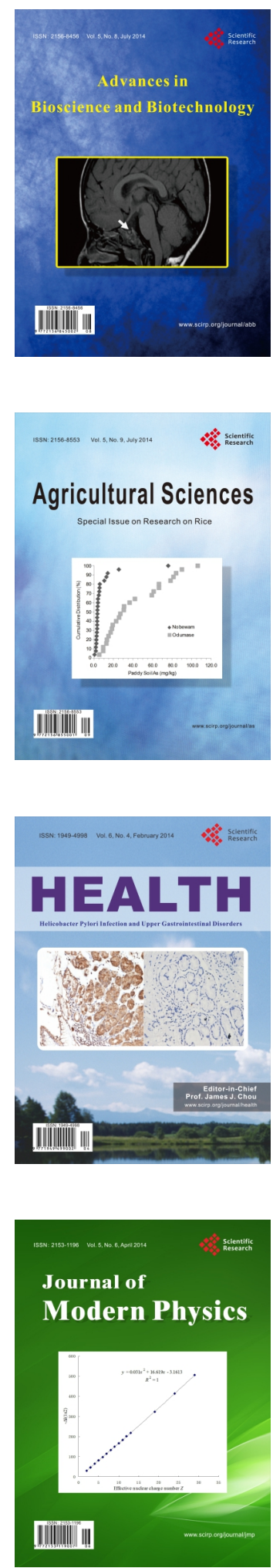
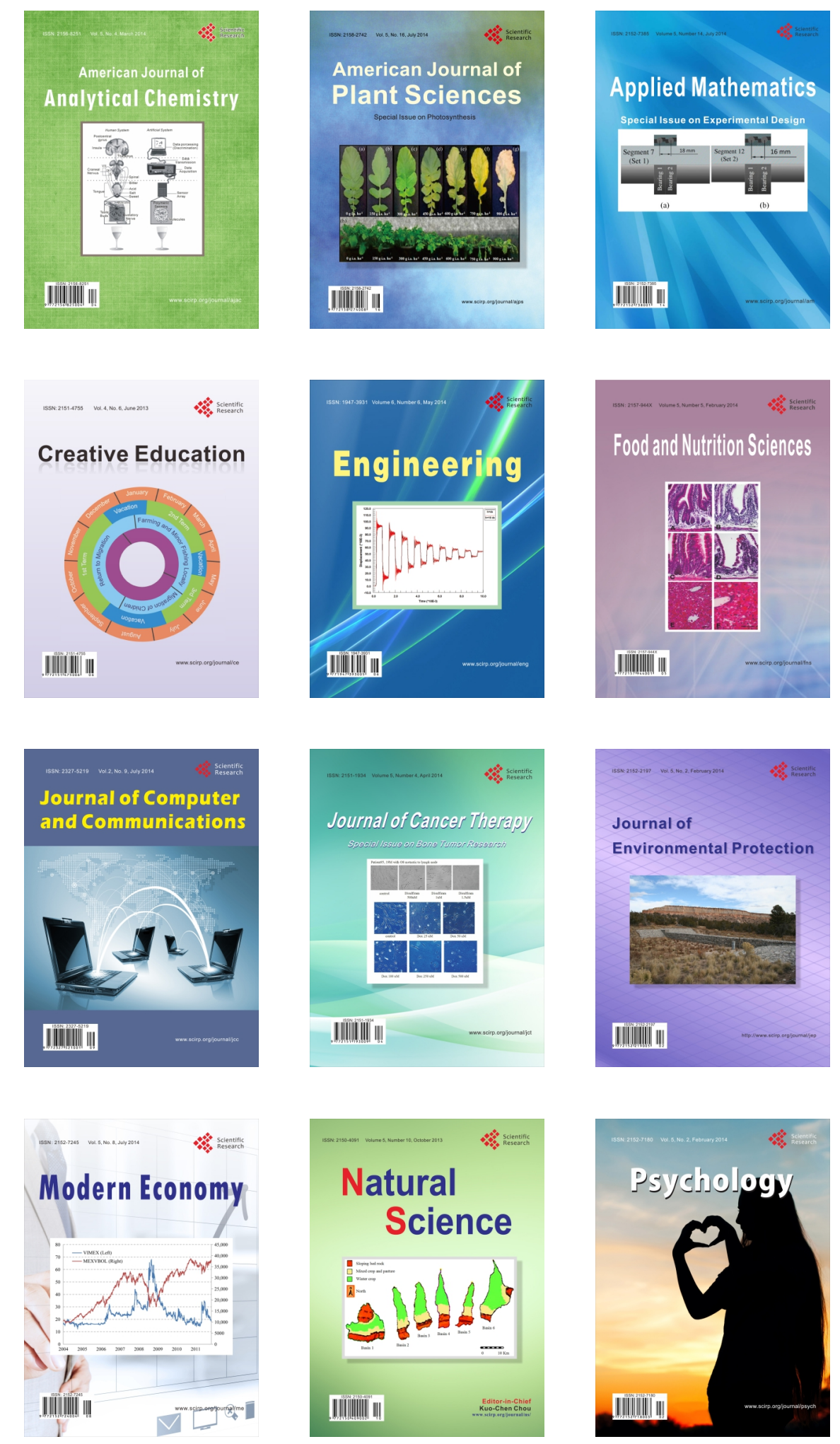